\title{
Dynamics of Starch Reserves in Some Grapevine Varieties (Vitis vinifera L.) During Dormancy
}

\author{
Anamaria CĂLUGĂR, Mirela Irina CORDEA*, Anca BABEŞ, Melinda FEJER \\ Faculty of Horticulture, University of Agriculture Sciences and Veterinary Medicine Cluj-Napoca, 3-5 \\ Manastur St., Cluj-Napoca, Romania \\ *corresponding author: mcordea@usamvcluj.ro
}

BulletinUASVM Horticulture 76(2) / 2019

Print ISSN 1843-5254, Electronic ISSN 1843-5394

DOI:10.15835/buasvmcn-hort: 2019.0008

\begin{abstract}
Carbohydrate reserves in grapevine are stored in form of starch and soluble sugars. The present study was conducted in order to understand the dynamics of insoluble carbohydrate reserves during dormancy season of some table and wines grapevine varieties. Six year old grapevine varieties (Muscat de Hamburg, Napoca, Cardinal, Perla de Csaba, Fetească regală, Muscat Ottonel, Pinot noir and Fetească neagră) were sampled before winter. During dormancy, starch level in canes was appreciated by iodin in potassium iodide method, wood and pith diameter measured and bud viability tested. The levels of starch in grape canes at the beginning of dormancy (November) was highest in Muscat de Hamburg (3.89), Napoca and Fetească regală (3.76) and the lowest in Cardinal (3.47). Due to climatic conditions over dormancy, starch began to resynthesize already during January and February, with significantly high levels for all varieties. Wood/pith ratio was highly correlated with starch level. Bud viability was directly influenced by the starch level in canes.
\end{abstract}

Keywords: dormancy, grapevine, starch

\section{Introduction}

Carbohydrate reserves are important in the grapevine growth cycle because they are a source that supports new growth following bud break. The amount of reserves stored during winter influences reproductive development and shoot growth in the following vegetation season (Bennett et al., 2005). According to the research undertaken by Vaillant-Gaveau et al. (2014), starch and soluble sugars are the forms in which carbohydrate reserves are stored in grapevine. Towards the end of the growing season, a peak level of starch reserves in aerial parts can be observed. As the dormancy period begins, starch concentrations start to decrease. In the same time, due to the conversion of starch, soluble sugar (cryoprotectant) levels begin to increase (Noronha et al., 2018). The conversion of carbohydrates is reversed and at the end of dormancy, starch increases and soluble sugar decreases (Zufferey et al., 2015).

Kovaleski et al. (2018) consider dormancy as being the temporary stagnation of visible growth of buds that can be divided in three steps: para-, endo- and ecodormancy.

Starch and soluble sugars storage begins in the main reserve organs (canes, trunk and roots) when the plant requirements for growth and fruit production have been satisfied (Zapata et al., 2004).

Carbohydrates (starch and soluble sugars) utilization and storage during the season depend on environmental conditions such as temperature (cool or hot climate) (Londo and Kovaleski, 2019), 
water reserve (Pellegrino et al., 2014), light level (Schreiner et al., 2012) and plant factors such as photosynthetic conditions (Bates et al., 2002).

Vineyard distribution around the world is limited by the low temperature. The level of frost resistance acquired during the dormancy by Vitis spp. is crucial for winter survival (Antivilo et al., 2017). Winter resistance was correlated with vine varieties accumulation of carbohydrates, depending on shoots or canes vigour (Samra, 2008).

The presence of starch interfered directly with winter tolerance, due to the fact that plants use starch to produce other metabolites or energy, which offer frost resistance (Noronha et al., 2018). In grapevine, carbohydrates accumulated in perennial organs during the previous year support the early development of annual organs (Bates et al., 2002; Noronha et al., 2018).

Considering the above mentioned facts, the aim of the present study is to understand the dynamics of starch reserve during the dormancy season of some table and grapevine varieties.

\section{Materials and methods}

The experiment was conducted during 2018-2019 dormancy period, on Vitis vinifera L. Cultivars were: 'Muscat de Hamburg', 'Napoca',
'Cardinal', 'Perla de Csaba', 'Fetească regală', 'Muscat Ottonel', 'Pinot noir' and 'Fetească neagră'. The vineyard was planted in 2013 at the University of Agricultural Sciences and Veterinary Medicine (UASVM) from Cluj Napoca, Romania $\left(46^{\circ} 46^{\prime} \mathrm{N}\right.$; $23^{\circ} 35^{\prime} \mathrm{E}$ ). Grapevines were cane pruned (2 canes of 8-9 buds/vine) with the same trunk height (0.7$0.8 \mathrm{~m}$ ). Planting densities were 4545 vines/ha $(2.0 \mathrm{~m} \times 1.1 \mathrm{~m})$. The soil of the vineyard is haplic luvisols, deep and fertile, with high water holding capacity. Monthly temperature and precipitation are reported in Table 1 . The climatic data were collected from the weather station located near to the plot for the current experiment.

Samples of one year old canes were collected from five vine plant from each variety during dormancy (in the middle of November, January and February). Each cane sample was measured (cane and pith diameter) and bud viability tested, on base, middle and top of the cane. The canes of each variety of grapevines were used so as to determine the insoluble carbohydrate reserve concentrations (starch). Wood samples were cut in small pieces of 70-90 m and treated with iodine in potassium iodide (Cordea, 2014). The starch content was appreciated by grading the sections on a scale of 0 to 5 depending on the presence of the starch in the canes' tissues as follows:

Table 1. The climatic data at UASVM Cluj-Napoca during the analysed period (2018-2019)

\begin{tabular}{cccccccccccc}
\hline \multirow{2}{*}{$\begin{array}{l}\text { Month/ } \\
\text { climate }\end{array}$} & IV & V & VI & VII & VIII & IX & X & XI & XII & I & II \\
\cline { 2 - 12 } & & & & & $\mathbf{2 0 1 8}$ & & & & & 2019 \\
\hline Mean T ${ }^{\circ} \mathrm{C}$ & 14.9 & 18.2 & 19.3 & 20.4 & 21.9 & 16.3 & 12.0 & 6.2 & -0.1 & -1.7 & 2.0 \\
\hline${\text { Min } \mathrm{T}^{\circ} \mathrm{C}}^{\circ}$ & 7.4 & 10.6 & 14.7 & 13.6 & 15.3 & 9.6 & 5.3 & -11.0 & -13.0 & -16.0 & -5.0 \\
\hline Max T ${ }^{\circ} \mathrm{C}$ & 22.1 & 25.6 & 26.4 & 25.8 & 29.8 & 23.6 & 19.8 & 12.0 & 2.2 & 0.9 & 6.9 \\
\hline Precipitation $(\mathrm{mm})$ & 17.77 & 36.06 & 174.77 & 61.96 & 21.07 & 36.58 & 47.75 & 17.02 & 56.14 & 55.88 & 17.53 \\
\hline
\end{tabular}
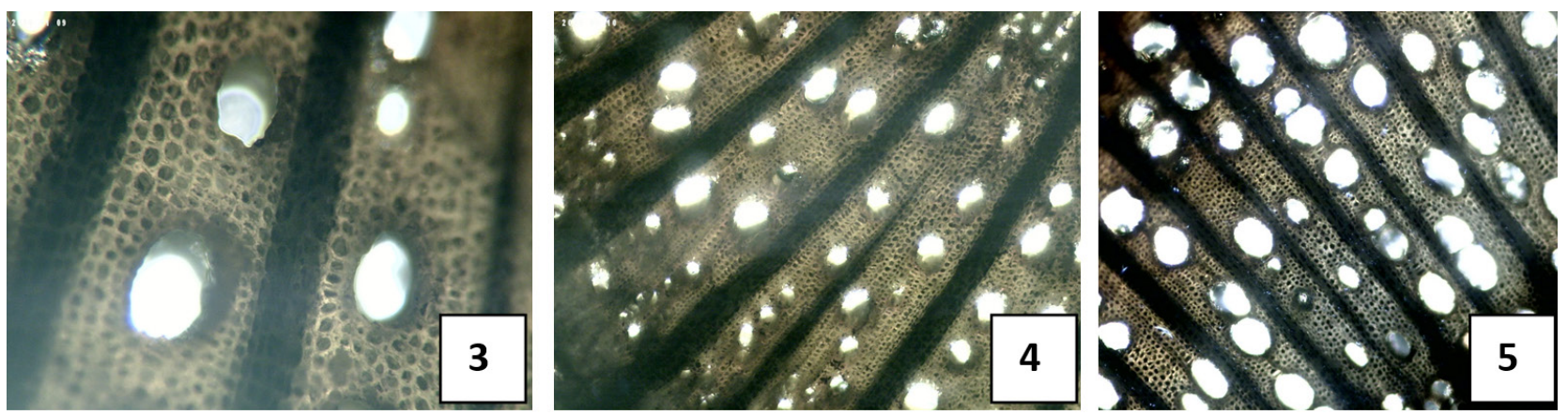

Figure 1. The starch content on sections marked with notes from 3 to $5(10 \times)$ 
Note 0 - when there is no starch in any cane tissues;

Note 1 - when the starch is present only in medullary ray up to the xylem area;

Note 2 - when the starch is in medullary ray, a few in xylems and not found in phloem;

Note 3 - when the starch is present in medullary ray, xylem and a few in phloem;

Note 4 - when the starch can be identified in all tissue sections, but without completely filling up all cells;

Note 5 - when all cells of sections are filled with starch.

All sections were analysed with $10 \times$ microscope objective and noted with 3 to 5 in all eight Vitis cultivars that were analysed (Fig. 1). The current experiment did not have any section marked with 0,1 and 2 notes.

This method is simple, incipient, low cost, easy, and is used to evaluate the starch content for different grape varieties before spring pruning or in breeding fields.

\section{Statistical analysis}

The data were analysed using variance analysis (ANOVA) and the Duncan test $(p \leq 0.05)$ was performed to emphasise the significant differences between cultivars. Between the different variables calculated, a number of parabolic correlations were highlighted, and the correlation coefficient was calculated, which expresses the intensity of the relation between the two variables.

\section{Results and discussions}

Cluj-Napoca $\left(46^{\circ} 46^{\prime} \mathrm{N}, 23^{\circ} 36^{\prime} \mathrm{E}\right)$ is situated in central Transylvania in the Somesul Mic Corridor, being located within three major geographical units: the Transylvanian Plain, the Somes Plateau, and the Apuseni Mountains (Boanca et al., 2018). The climatic data from Cluj state an annual average temperature of $9.3^{\circ} \mathrm{C}$, with the highest temperatures in July $\left(36.3^{\circ} \mathrm{C}\right)$, while the absolute minimum may occur in January $\left(-21 \ldots .-23.0^{\circ} \mathrm{C}\right)$ (Lung et al., 2012; Bora et al., 2014a; Bora et al., 2014b).

Total rainfall received by the vines between budbreak (April) and leaf fall (October) was $395.96 \mathrm{~mm}$ for 2018 growing season (Tab. 1). Mean monthly temperatures during the vegetation period were $0.5-1.0^{\circ} \mathrm{C}$ lower than the multiannual average (Lung et al., 2012).
During dormancy period 2018-2019, in Cluj Napoca area, the lowest temperatures were registered at the end of November $\left(30^{\text {th }}:-10 \ldots-\right.$ $\left.11^{\circ} \mathrm{C}\right)$, at the beginning of December $\left(1^{\text {st }}-2^{\text {nd }}\right.$ : $\left.-12 \ldots-13^{\circ} \mathrm{C}\right)$ and in January $\left(5^{\text {th }}-8^{\text {th }}:-11 \ldots-16^{\circ} \mathrm{C}\right)$. According to this data, it can be stated that there were very short periods with temperatures below $-10^{\circ} \mathrm{C}$, far from grapevine temperature frost resistance $\left(-22 \ldots-24^{\circ} \mathrm{C}\right)$. During winter, Chmielewski et al. (2018) have observed that there is a possibility of rise in incidents of acute cold weather in the northern hemisphere, despite the fact that average global temperatures are increasing. Cluj Napoca is not included in the winegrowing areas of Romania, according to Order no. $225 / 2006$ regarding the approval of the zoning of the Vitis vinifera grape varieties admitted for planting. Nevertheless, some table grape varieties (Napoca, Cetățuia, Timpuriu de Cluj) were created in this area to satisfy consumers' need for local products given the appropriate climate conditions of the area.

Summer and autumn weather events have an influence on starch synthesizing, dormancy and cold hardiness transitions which can affect vulnerability to frost injury and have real implications under global climate change (Cragin et al., 2017).

In November, by analysing each grapevine variety, it has been noted that starch content level varied between varieties. The highest starch level was recorded in 'Muscat de Hamburg' (3.88). The 'Napoca' and 'Fetească regală' varieties studied were statistically equal (3.78). A lower starch content level was recorded in the case of the three varieties: 'Fetească neagră' and 'Perla de Csaba' (3.55), 'Pinot noir' (3.55) and 'Cardinal' (3.46). The results of the present study indicate that, although the studied varieties are table and wine grapes, there is no distinct difference depending on the direction of production as for the starch content. Therefore, the results show the different potential of the genetic determinants for wood ripening which may be correlated with frost resistance as demonstrated by Dobrei et al. (2015).

Due to the temperature during winter in Cluj Napoca, between 0 and $-5 . .-7^{\circ} \mathrm{C}$, and the abundant snow precipitations, surprisingly, starch content in canes starts to resynthesize, thus, in the middle of January, it was significantly higher than in November. In the middle of January, the highest 


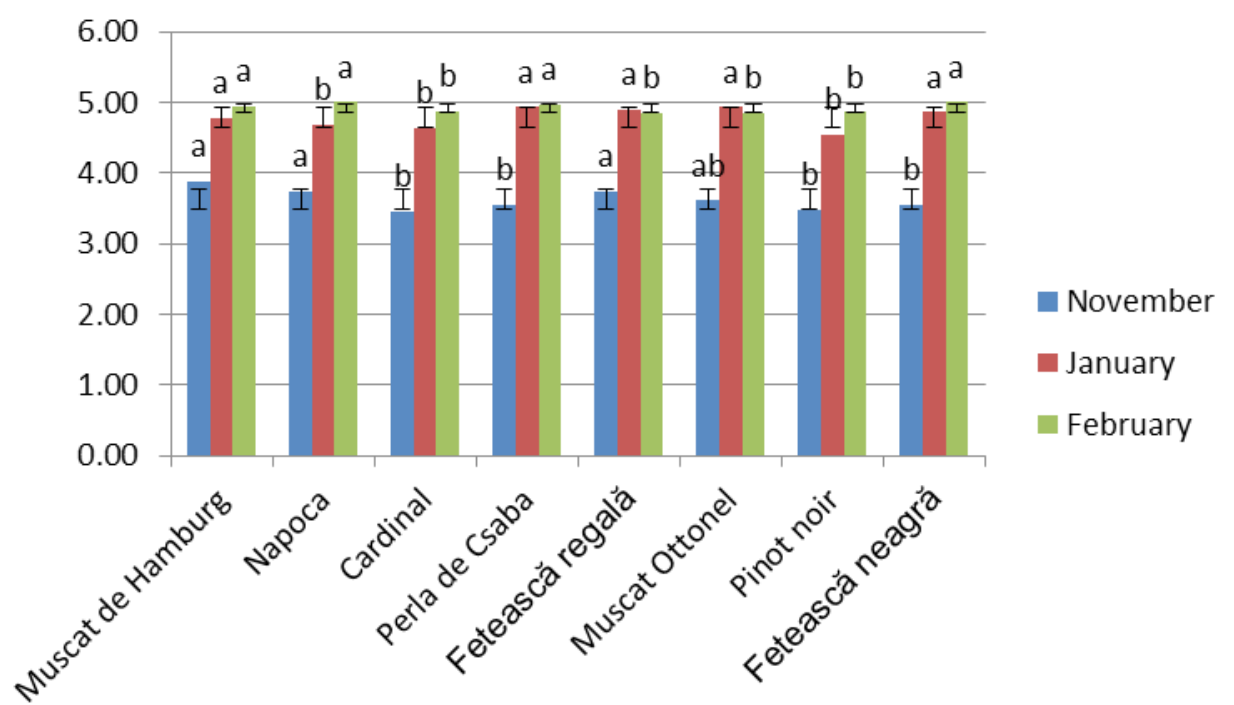

Figure 2. Starch level in canes over the 2018/2019 winter conditions Error bars indicate the standard error of the mean at the $5 \%$ level of probability $(n=5)$.

The difference between any two values, followed by at least one common letter, is insignificant $(p \leq 0.05)$.

content of starch was appreciated for 'Perla de Csaba', 'Muscat Ottonel' and 'Fetească regală' (4.90), significantly higher than for 'Napoca' (4.68), 'Cardinal' (4.63) and 'Pinot noir' (4.55). After another month, in the middle of February, the level of starch appreciated was the highest for 'Napoca' and 'Fetească neagră' (5.00), very close to 'Perla de Csaba' (4.97) and 'Muscat de Hamburg' (4.95). The lowest level of starch appreciated in canes in February was for 'Muscat Ottonel', 'Pinot noir' (4.86) and 'Fetească regală' (4.84). Air temperature, relative humidity, daily thermal amplitude and genotype are considered to be the main triggering factors of this pattern according the studies undertaken by Londo and Kovaleski (2017), Antivilo et al. (2017). Starch accumulation in grape canes and buds is associated with dormancy. Starch breakdown and the subsequent increase in sugar content are associated with cold hardiness (Rubio et al., 2015).

A new polymerization process takes place due to increasing temperatures, thus in spring, the amount of starch and soluble sugars would be in balance. It has been demonstrated that wild grapevine species with northern spreading have a tendency to exhibit higher cold resistance and responsiveness to temperature fluctuations than southern species (Kovaleski et al., 2018). The same authors suggest that future grapevine improvements can be sustained through the investigation and mapping of temperature responsiveness. Wood ripening of grape canes has been related with resistance to winter frost and buds viability, but it was also associated with the biological material (Dobrei et al., 2015).

Distinctly significant parabolic regressions are obtained by establishing, in this case, a strong relationship between wood/pith ratio and starch content during dormancy (Fig. 3). The values of the correlation coefficient were distinctively significant for data in November $\left(\mathrm{r}=0.55^{* *}\right)$, January $\left(\mathrm{r}=0.54^{* *}\right)$ and February $\left(\mathrm{r}=0.48^{* *}\right)$. As it is shown in the graphical representation, in all the three moments of determination, wood/ pith ratio and starch content are in direct relation until a point and then start to decrease. This may be explained by the fact that vigorous canes tend to have lower starch levels, as carbohydrates are flowing rapidly to the new growth and are not available to the buds. Some studies (Samra, 2008) have found less content of starch in vigorous canes, but the correlation is not strong, and not found in all studies (Călugăr et al., 2010). Vigorous growth during the vegetation period also increases shading which enhances the necrosis of shoots. It requires farming practices that remove excessive growth and it might improve fruitfulness and good wood ripening.

In many plant species, the increase of total soluble sugars and the decrease in starch content 


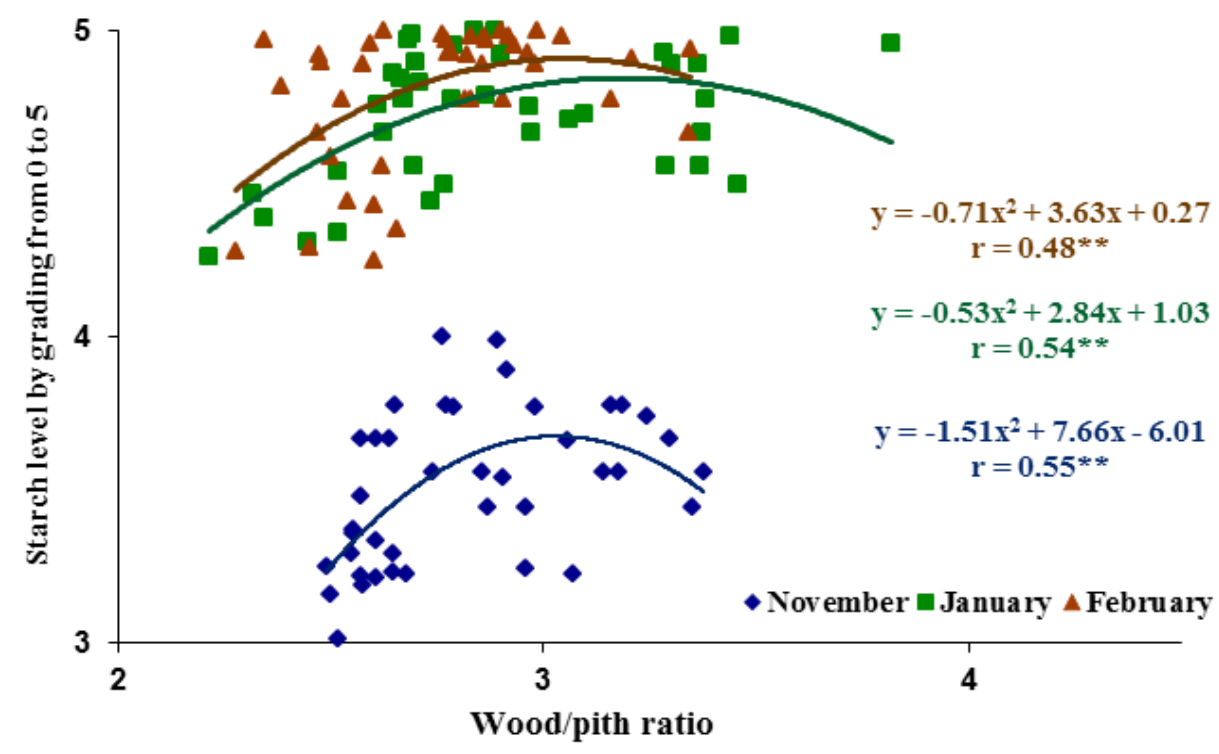

Figure 3. Correlations between wood/pith ratio and starch content, during dormancy 2018-2019

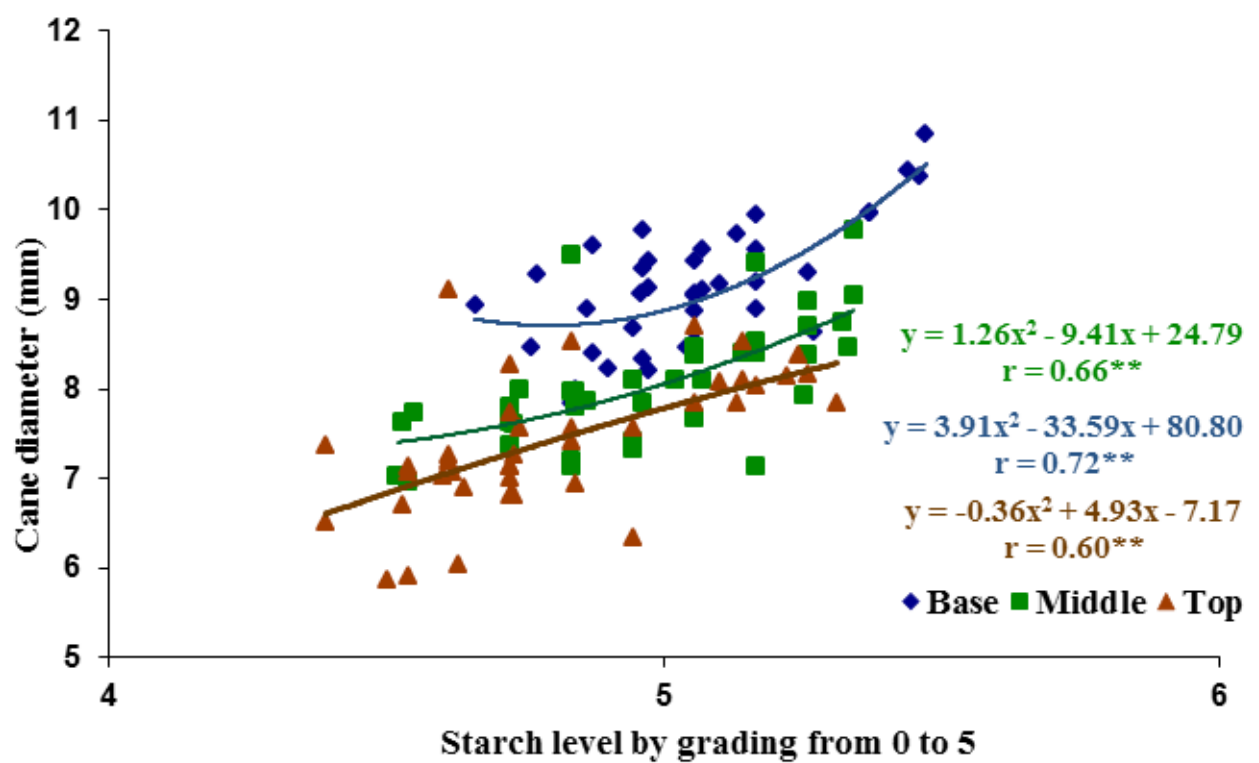

Figure 4. Correlations between starch content and cane (base, middle and top) diameter, during dormancy 2018-2019

have been observed directly with an increase in frost temperature resistance. Starch accumulation in grape buds and canes was associated with the beginning of dormancy. The starch breakdown and the increase in sugar content are associated with cold hardiness (Rubio et al., 2015).

Between starch content and cane zone (base, middle) there is a strong positive relation shown by the correlation coefficient (base - $r=0,72^{* *}$; middle $-\mathrm{r}=0.66^{* *}$ ) and negative relation for the top zone of the cane ( $\mathrm{r}=0.60^{* *}$ ) (Fig. 4). Those relations show a higher content in starch at the base and in the middle of the canes. The same results were obtained by Sala and Dobrei (2017) who also correlate the cane diameter with water loss parameter.

Sommer et al. (2000) state that the starch concentration decreases at higher node positions in a cane and it is correlated with a decrease in inflorescences per shoot at the top of the canes. 


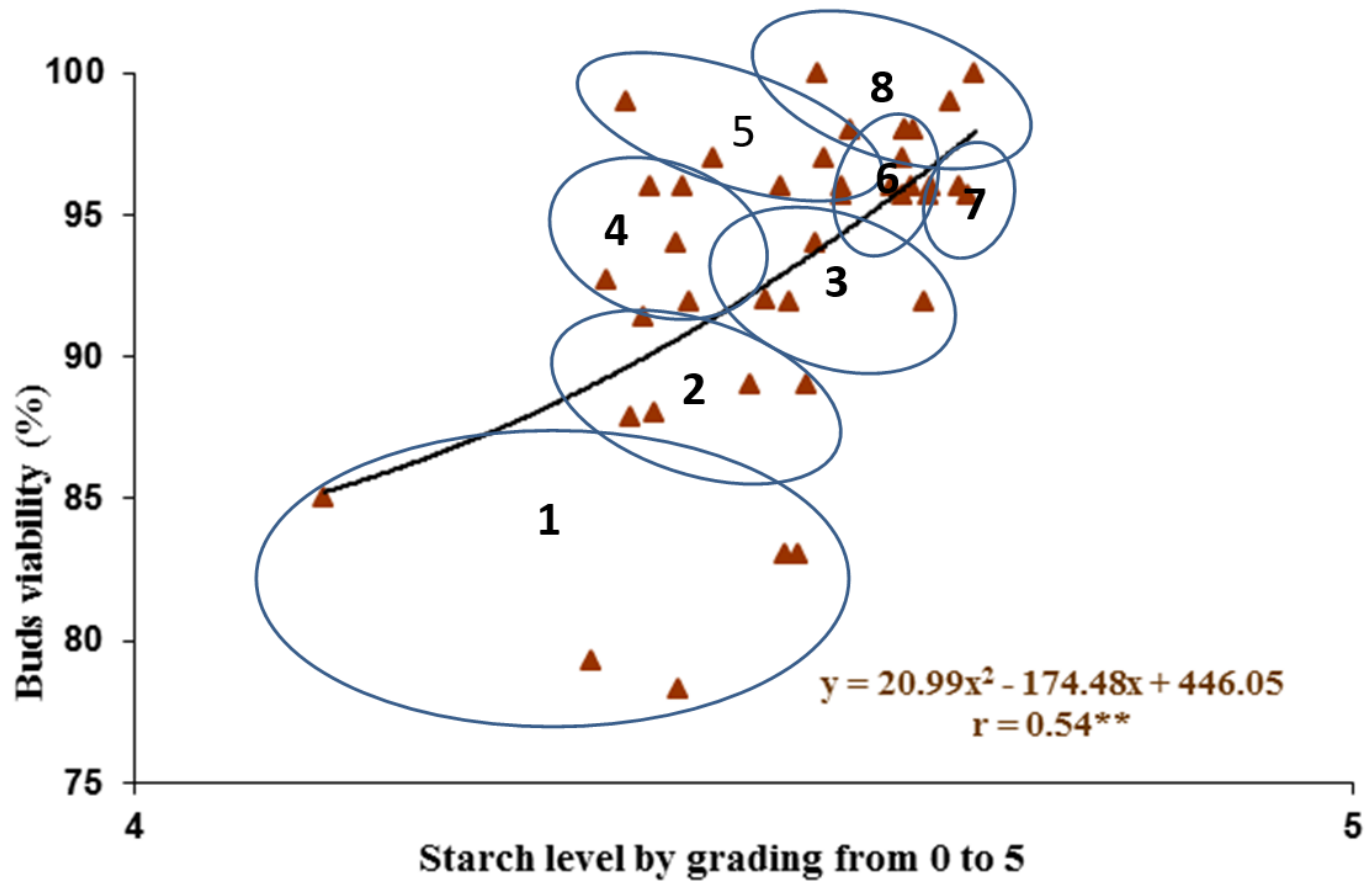

Figure 5. Correlations between starch content and bud viability, during dormancy 2018-2019

1-'Cardinal', 2-'Fetească regală', 3-'Fetească neagră', 4-'Muscat Ottonel', 5-'Fetească neagră', 6-'Perla de Csaba', 7-'Muscat de Hamburg', 8-'Napoca'

Also, the effect of pruning to high bud load may result in exhaustion of starch reserves and have long-term effects on yield and quality. Pruning treatment significantly affected starch content of the winter canes (Heazlewood et al., 2006).

Grapevine varieties that genetically tend to have more carbohydrates also tend to be more resistant to frost during winter. Vasudevan (1997) found that low bud viability in several grapevine varieties is due to low carbohydrate ('Riesling', 'Syrah' and 'Viognier'), and high bud viability in 'Chardonnay' with large amount of carbohydrate. Călugăr et al. (2010) found a negative strong correlation between the starch content and bud viability for 'Astra', 'Blasius', 'Selena' and 'Fetească regală' during winter 2009-2010. Thus, 'Fetească regală' with a carbohydrate content of 13.09 $\mathrm{g} \%$, has above $50 \%$ buds viability, while 'Astra', 'Blasius' and 'Selena', with a content of reserve substance more than $14.50 \mathrm{~g} \%$, and have less than $40 \%$ viable buds. This may be explained by the fact that vigorous canes tend to have lower starch levels, as carbohydrates are flowing rapidly to the new growth and are not available to the buds.

Due to the climatic conditions during dormancy 2018-2019, almost all studied varieties have good bud viability, $90 \%$ to $100 \%$. 'Cardinal' variety has the lowest bud viability (75\%-80\%) and the lowest starch content, as is showed in Figure 5. From the graphical representation is noted that the experimental results show a strong relationship between starch content in canes and bud viability (Fig. 5) with a high correlation coefficient ( $\left.\mathrm{r}=0.54^{* *}\right)$. Bud viability has an important interest in pruning and grafting. Moreover, as Sala and Dobrei (2017) mention, bud viability is in direct relation with the content of mineral elements and starch cane content and in indirect relation with cane water content. Those elements are influenced by grape variety, technological management and climatic conditions (Dobrei et al., 2015; Heazlewood et al., 2006; Călugăr et al. 2010).

\section{Conclusions}

The results of the present study emphasise that the mean temperature during dormancy $(0 \ldots-$ $5^{\circ} \mathrm{C}$ ) influences the resynthesis of starch earlier, in the middle of January. Very short periods with temperature lower than $-10^{\circ} \mathrm{C}$ in November, December and January, did not affect bud viability. 
The present research confirms the close and strong correlation between cane vigour and starch reserves. Moreover, starch level was in direct relationship with bud viability and frost resistance. The findings of the present research show the different potential of the genetic determinants for wood ripening which may be correlated with frost resistance. The experimental results demonstrate a strong relationship between starch content in canes and bud viability.

Acknowledgements: This research work is funded by the Ministry of Research and Innovation of Romania, Projects for Financing the Excellence in CDI, Contract no. 37PFE/06.11.2018.

\section{References}

1. Antivilo FG, Paz RC, Keller M, Borgo R, Tognetti J, Juñent FR (2017). Macro- and microclimate conditions may alter grapevine deacclimation: variation in thermal amplitude in two contrasting wine regions from North and South America. International Journal of Biometeorology, 61(12): 2033-2045.

2. Bates TR, Dunst RM, Joy P (2002). Seasonal dry matter, starch, und nutrient distribution in Concord grapevine roots. Horticultural Science, 37: 313-316.

3. Bennett J, Jarvis P, Creasy GL, Trought MCT (2005). Influence of defoliation on overwintering carbohydrate reserves, return bloom, and yield of mature Chardonnay grapevines. American Journal of Enology and Viticulture, 56: 386-393.

4. Boancă P, Dumitraş A, Luca L, Bors-Oprişa S, Laczi E (2018). Analysing bioretention hydraulics and runoff retention through numerical modelling Using RECARGA: a case study in a Romanian urban area. Polish Journal of Environmental Studies, 27(5): 1965-1973.

5. Bora FD, Pop TI, Babeș AC, Popescu D, Iliescu M, Pop N (2014a). Research on the quality of the three white wine varieties in Transylvania, harvest of 2013-14. Bulletin UASVM Horticulture, 72(2): 327-334.

6. Bora FD, Pop TI, Bunea CI, Urcan DE, Babeș A, Cozmuta ML, Cozmuta MA, Pop N (2014b). Influence of ecoclimatic and ecopedological conditions on quality of white wine grape varieties from North-West of Romania. Bulletin UASVM Horticulture, 71(2): 218-225.

7. Călugăr A, Pop N, Farago M, Babeș A, Bunea CI, Hodor D, Cioabanu F (2010). Buds viability and carbohydrates canes content of some varieties created at S.C.D.V.V. Blaj during winter 2009-2010. Lucrări ştiinţifice USAMVB, Seria B, LIV: 548-553.

8. Chmielewski FM, Götz KP, Weber KC, Moryson S (2018). Climate change and spring frost damages for sweet cherries in Germany. International Journal of Biometeorology, 62: 217-228.

9. Cordea MI (2014). Plant Breeding - practical works. ClujNapoca: AcademicPres.
10. Cragin J, Serpe M, Keller M, Shellie K (2017). Dormancy and cold hardiness transitions in winegrape cultivars Chardonnay and Cabernet Sauvignon. American Journal of Enology and Viticulture, 68: 195-202.

11. Dobrei A, Dobrei AG, Nistor E, Iordanescu OA, Sala F (2015). Local grapevine germplasm from Western of Romania - An alternative to climate change and source of typicity and authenticity. Agriculture and Agricultural Science Procedia, 6: 124-131.

12. Heazlewood JE, Wilson S, Clark R J, Gracie AJ (2006). Pruning effects on Pinot Noir vines in Tasmania (Australia). Vitis, 45 (4): 165-171.

13. Kovaleski AP, Reisch BI, Londo JP (2018). Deacclimation kinetics as a quantitative phenotype for delineating the dormancy transition and thermal efficiency for budbreak in Vitis species, AoB PLANTS 10: ply066.

14. Londo JP, Kovaleski AP (2017). Characterization of wild north american grapevine cold hardiness using differential thermal analysis. American Journal of Enology and Viticulture, 68: 203-212.

15. Londo JP, Kovaleski AP (2019). Deconstructing cold hardiness: variation in supercooling ability and chilling requirements in the wild grapevine Vitis riparia. Australian Journal of Grape and Wine Research, 1:10.

16. Lung ML, Pop N, Ciobanu F, Babeș A, Bunea CI, Lazar S (2012). Environmental factors influence on quality of wine grape varieties in four different areas of culture. Bulletin UASVM Horticulture, 69(1): 219-227.

17. Noronha H, Silva A, Dai Z, Gallusci P, Rombolà AD, Delrot S, Gerós H (2018). A molecular perspective on starch metabolism in woody tissues. Planta, 248: 559-56.

18. Pellegrino A, Clingeleffer P, Cooley N, Walker R (2014). Management practices impact vine carbohydrate status to a greater extent than vine productivity. Front. Plant Sci., 5: 283

19. Rubio S, Dantas D, Bressan-Smith R, Perez FR (2015). Relationship between endodormancy and cold hardiness in grapevine buds. J Plant. Growth Regul. DOI 10.1007/ s00344-015-9531-8.

20. Sala F, Dobrei A (2017). The rate of water loss in relation to internodes position and wood maturity in canes of the grapevine. Bulletin UASVM Horticulture, 74(1): 39-45.

21. Samra BN (2008). Suitable cane thickness retained on superior grapevine at winter pruning. Journal of Agricultural Sciences of Mansoura University, 33(4): 2781-2789.

22. Schreiner RP, Kerton JN, Zasada IA (2012). Delayed response to ring nematode (Mesocriconema xenoplax) feeding on grape roots linked to vine carbohydrate reserves and nematode feeding pressure. Soil Biochemistry, 45: 8997.

23. Sommer KI, Islam MT, Clingeleffer PR (2000). Light and temperature effects on shoot fruitfulness in Vitis vinifera L. cv. Sultana: Influence of trellis type and grafting. Australian Journal of Grape and Wine Research, 6: 99-198.

24. Vaillant-Gaveau N, Wojnarowiez G, Petit A-N, Jacquens L, Panigai L, Clément C, Fontaine F (2014). Relationships between carbohydrates and reproductive development 
in Chardonnay grapevine: impact of defoliation and fruit removal treatments during four successive growing seasons. Journal International des Sciences de la Vigne et du Vin, 48: 219-229.

25. Vasudevan L (1997). Anatomical developments and the role of carbohydrate or mineral nutrient deficiency in bud necrosis of Riesling grapevines, PhD Dissertation, Virginia

26. Zapata C, Deléens E, Chaillou S, Magné C (2004). Partitioning and mobilization of starch and $\mathrm{N}$ reserves in grapevine (Vitis vinifera L.). Journal of Plant Physiology, 161: 1031-1040.

27. Zufferey V, Murisier F, Vivin P, Belcher S, Lorenzini F, Spring $\mathrm{J}$-L, Viret $O$ (2015). Carbohydrate reserves in grapevine (Vitis vinifera L.'Chasselas'): the influence of the leaf to fruit ratio. VITIS - Journal of Grapevine Research, 51:103.

28. *** Order no. 225/2006 regarding the approval of the zoning of the grape varieties of admitted in culture in the wine-growing areas of Romania 